University of New Hampshire

University of New Hampshire Scholars' Repository

$12-2005$

\title{
How the Justice System Responds to Juvenile Victims: A Comprehensive Model.
}

\author{
David Finkelhor \\ University of New Hampshire - Main Campus, David.Finkelhor@unh.edu \\ Theodore P. Cross \\ University of New Hampshire - Main Campus \\ Elise N. Cantor \\ University of New Hampshire - Main Campus
}

Follow this and additional works at: https://scholars.unh.edu/ccrc

Part of the Criminology and Criminal Justice Commons, Psychology Commons, Social Work Commons, and the Sociology Commons

\section{Recommended Citation}

Finnkelhor, David; Cross, Theodore P. \& Cantor, Elise. How the justice system responds to juvenile victims: A comprehensive model. Juvenile Justice Bulletin - NCJ210951 (pgs. 1-12). Washington, DC: Office of Juvenile Justice and Delinquency Prevention.

This Article is brought to you for free and open access by the Research Institutes, Centers and Programs at University of New Hampshire Scholars' Repository. It has been accepted for inclusion in Crimes Against Children Research Center by an authorized administrator of University of New Hampshire Scholars' Repository. For more information, please contact Scholarly.Communication@unh.edu. 


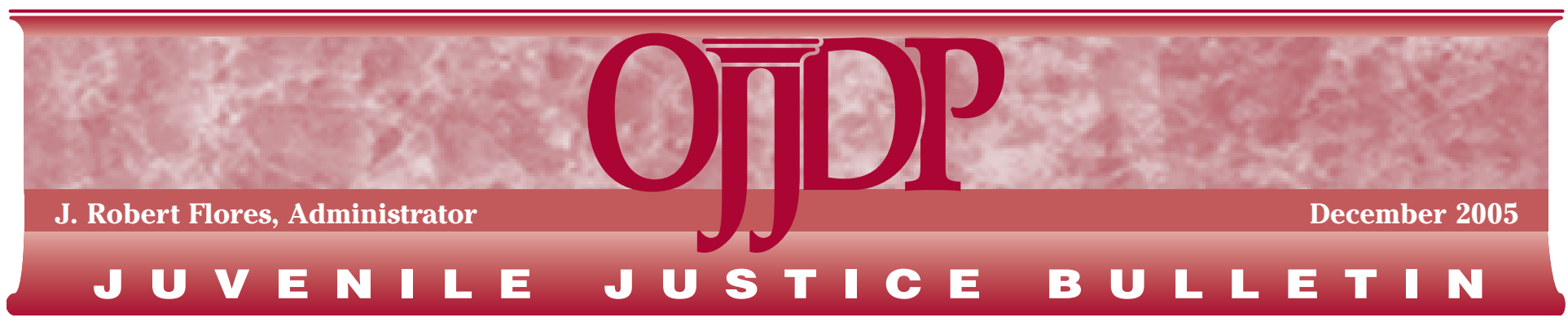

Office of Justice Programs • Partnerships for Safer Communities • www.ojp.usdoj.gov

\section{How the Justice System Responds to Juvenile Victims: A Comprehensive Model}

\section{David Finkelhor, Theodore P. Cross, and Elise N. Cantor}

The Office of Juvenile Justice and Delinquency Prevention (OJJDP) is committed to improving the justice system's response to crimes against children. OJJDP recognizes that children are at increased risk for crime victimization. Not only are children the victims of many of the same crimes that victimize adults, they are subject to other crimes, like child abuse and neglect, that are specific to childhood. The impact of these crimes on young victims can be devastating, and the violent or sexual victimization of children can often lead to an intergenerational cycle of violence and abuse. The purpose of OJJDP's Crimes Against Children Series is to improve and expand the nation's efforts to better serve child victims by presenting the latest information about child victimization, including analyses of crime victimization statistics, studies of child victims and their special needs, and descriptions of programs and approaches that address these needs.

This Bulletin introduces the concept that a justice system exists that responds to juvenile victims. This juvenile victim justice system is a complex set of agencies and institutions that include police, prosecutors, criminal and civil courts, child protection agencies, children's advocacy centers, and victim services and mental health agencies. The system has a structure and sequence, but its operation, despite the thousands of cases it handles every year, is not as widely recognized and understood as the operation of the more familiar juvenile offender justice system. ${ }^{1}$
The juvenile victim justice system is not as widely recognized in part because it is a fragmented system. It has not been conceptualized as a whole or put into place by a common set of statutes in the way the juvenile offender system has. Many of the agencies that handle juvenile victims are part of other systems, not designed primarily with juvenile victims in mind.

\footnotetext{
${ }^{1}$ This Bulletin was adapted by the authors, with permission, from "The Justice System for Juvenile Victims: A Comprehensive Model of Case Flow" in Trauma, Violence, \& Abuse 6(2):83-102 (2005).
}

\section{A Message From OJJDP}

The justice system handles thousands of cases involving juvenile victims each year. These victims are served by a complex set of agencies and institutions, including police, prosecutors, courts, and child protection agencies. Despite the many cases involving juvenile victims and the structure in place for responding to them, the juvenile victim justice system model presented in this Bulletin is a new concept.

Although the juvenile victim justice system has a distinct structure and sequence, its operation is not very well understood. Unlike the more familiar juvenile offender justice system, the juvenile victim justice system has not been conceptualized as a whole or implemented by a common set of statutes.

This Bulletin identifies the major elements of the juvenile victim justice system by delineating how cases move through the system. It reviews each step in the case flow process for the child protection and criminal justice systems and describes the interaction of the agencies and individuals involved.

Recognizing how the juvenile victim justice system works can inform policy decisions and improve outcomes for juvenile victims. Acknowledging the existence of the system has important implications for system integration, information sharing, and data collection-all of which play a key role in ensuring the safety and well-being of juvenile victims. 
This Bulletin describes the major elements of the justice system for juvenile victims and what is known about how cases move through it. Like the system that handles juvenile offenders, the juvenile victim justice system is governed at the state level and implemented differently in each community, resulting in dissimilar practices and procedures from state to state. However, commonalities among these procedures can be described in a schematic way.

Recognizing how the juvenile victim justice system works is especially critical as policies about juvenile victims evolve and more professionals specialize in this area. Acknowledging the existence of a juvenile victim justice system can inform policy decisions and improve outcomes for juvenile victims. Other practical benefits, including victim assistance, information management, and system design, are discussed below.

The figure on page 3 shows how cases involving juvenile victims move through the juvenile victim justice system. Using the figure as a guide, this Bulletin reviews each step, from left to right, in the case flow process for the child protection and criminal justice systems. When possible, research evidence is reviewed at each step and implications for understanding and improving the response to child victims are discussed. For the sake of simplicity, atypical events that can occur within the system are omitted from the figure.

\section{Reported and Unreported Victimization}

Entry into the juvenile victim justice system begins with a report to an authorityusually either the criminal justice or child protection system. Estimates extrapolated from the National Incident-Based Reporting System suggest that in 1999 about 900,000 violent crimes against children were reported to the police nationwide. These crimes were predominantly assaults (77 percent) and sex offenses (20 percent). About 400,000 property crimes against juveniles (age 17 and younger) were also reported, mostly larceny and theft (77 percent) (Finkelhor and Ormrod, 2000b).

Each year, the National Child Abuse and Neglect Data System records about 2.6 million referrals to child protection

\section{Juvenile Victimization: Crime and Child Maltreatment}

One of the central complexities of the juvenile victim justice system is that it encompasses two distinct subsystems: the criminal justice system and the child protection system. These systems are typically thought of as separate, but the interaction between them in cases involving juvenile victims is considerable and increasing.

Officially, the two systems address different problems-crime and child maltreatment-but these domains overlap considerably. The crime domain, in terms of juvenile victims, includes all the offenses customarily seen as violent, such as homicides and physical and sexual assaults. But it also includes sex offenses such as incest and statutory rape, property crimes like theft, and criminal neglect. Across these crime categories, the justice system places no restriction on whom the perpetrator might be-family members, strangers, adults, or juveniles.

In contrast, statutes usually limit the domain of the child protection system (i.e., child maltreatment) to perpetrators who occupy a caretaking relationship to the child victim and thus tend to be adult family members or other caretakers. Child maltreatment is divided into the categories of physical and sexual abuse, neglect, and emotional maltreatment.

Direct overlap between the two systems primarily concerns sexual abuse and serious physical abuse, which are considered both child maltreatment and crimes because they involve assaults. Episodes of neglect and emotional maltreatment may or may not be crimes, depending on the acts and state statutes.

The concept of child maltreatment rarely includes property crimes, even when caretakers and family members commit them. Those professionals concerned with crimes against children also generally ignore property crimes, in part because they seem much less serious than violent crimes and sex offenses. Nonetheless, law enforcement agencies receive reports every year of hundreds of thousands of property crimes against juveniles (Finkelhor and Ormrod, 2000b), which research suggests have a significant and negative psychological impact on their victims (Norris and Kaniasty, 1994). These crimes need to be considered to better understand how the justice system responds to juvenile victims.

That the child protection system's mission can only be accomplished effectively through coordination with the criminal justice system has become increasingly clear. It has also become evident that the criminal justice system cannot provide true justice without ensuring the current and future protection of the child victims whose cases it processes. So, concerns about justice for and protection of juvenile victims have increasingly led professionals from each of the separate systems to look at how to better coordinate the investigative efforts of their systems.

authorities. Most of the referrals (59 percent) are for cases involving neglectful caretakers. An additional 19 percent are for physical abuse, and 10 percent are for sexual abuse (U.S. Department of Health and Human Services, 2001a). It is not clear how much overlap exists in these figures; that is, how many children were reported to both police and child protection services. In most police reports involving youth, the victims of violent crime are age 12 or older (71 percent), whereas cases reported to child protection services comprise predominantly younger children (74 percent younger than age 12). This difference suggests that the victim populations overlap only partially.
More than half (55 percent) of the reports made to the child protection system come from professionals who are legally mandated under state law to report suspicions of child maltreatment (U.S. Department of Health and Human Services, 2004). Of these, most come from teachers and educational professionals, followed by criminal justice and human services professionals. Direct reports from victims and families make up only 10 percent of the total.

In contrast, reports to police about juvenile victimization most often come from victims and families. Twenty-nine percent of reports involving the violent victimization of children come from the victims themselves, and 30 percent come from 
Figure: The Juvenile Victim Justice System

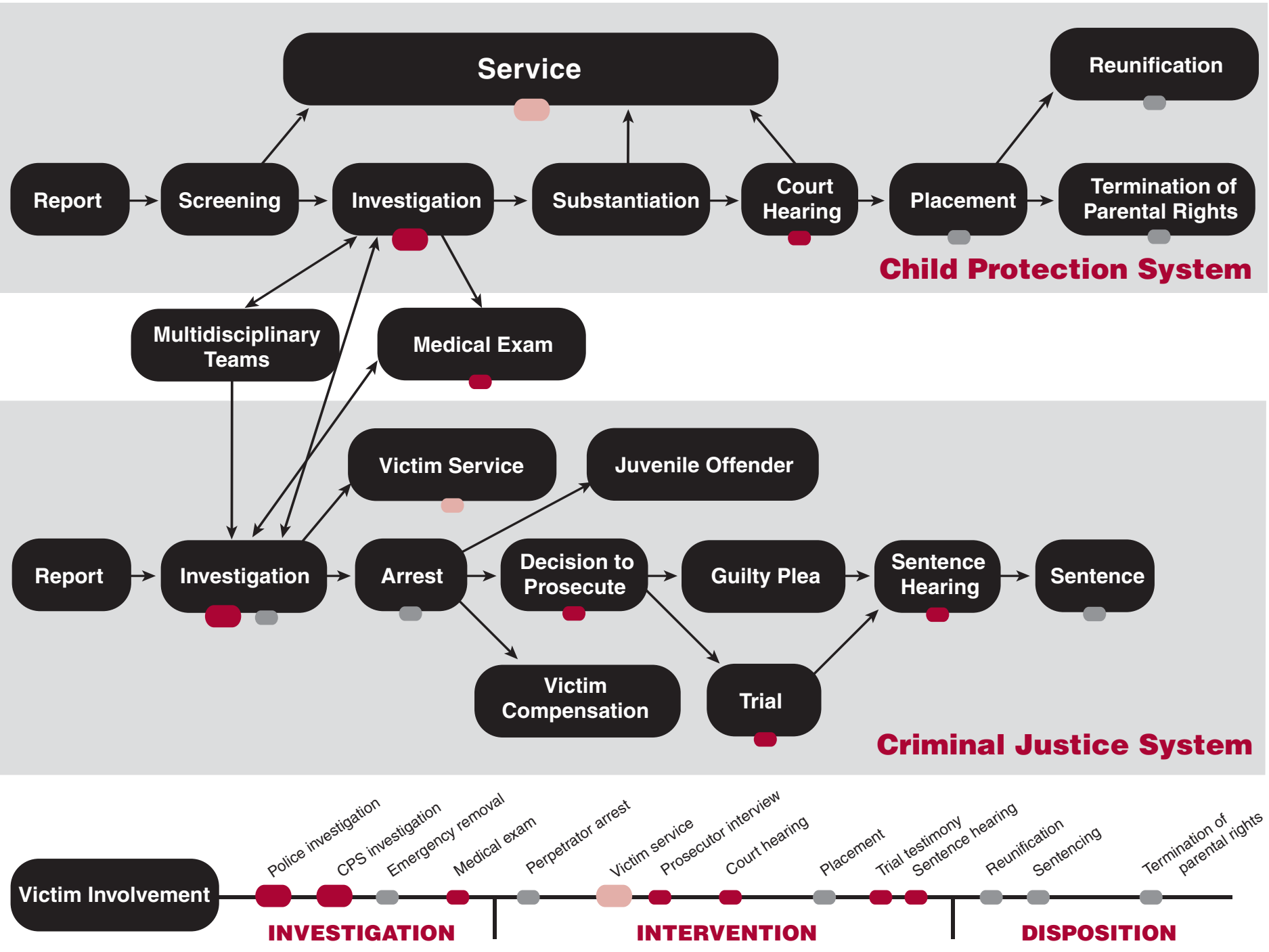

Large dot for high probability; small dot for low probability.

Interview/testimony $\square$ Service

Family Disruption

a member of the victim's household (Ormrod, 2002). For property crimes, the percentage of reports that victims or their family members submit is even higher. Reports to the criminal justice system from professionals such as school authorities are relatively infrequent (21 percent for violent crimes and 14 percent for property crimes), much less than the percentage of reports made from professionals to the child protection system. As might be expected, compared with adult victimizations, juvenile victimiza- tions are more often reported by family members and other officials than by the victims themselves.

Reported offenses, however, do not reflect the actual incidence of child maltreatment or crime victimization. As is widely recognized, a significant percentage of juvenile victims never come to the attention of police or child welfare authorities. According to the National Crime Victimization Survey, only 28 percent of violent crimes against youth ages 12-17 are reported to the police. This reporting rate for offenses against juveniles is substantially lower than for offenses against adults. Moreover, because the youngest children in the survey (the 12 year olds) have the lowest reporting rates, police are even less likely to receive reports involving victims younger than age 12 (Finkelhor and Ormrod, 1999). Crimes are more likely to be reported to the police when they involve injuries, adult or multiple offenders, or families with prior or existing contact with police (Finkelhor and Wolak, 2003). 
Because many schools are inclined to handle episodes involving juvenile victims on their own, the number of such crimes reported to the police is further limited.

Like the types of crimes mentioned above, child maltreatment is also widely underreported to authorities. The National Incidence Study of Child Abuse and Neglect (Sedlak and Broadhurst, 1996) found that only 28 percent of cases known to professionals in the community could be traced to any investigation that the local child protection system conducted. The percentage was higher for physical and sexual abuse (48 percent and 42 percent, respectively) than for neglect (18 percent). Although these statistics indicate underreporting by professionals, the data do not distinguish between professionals not reporting maltreatment and child protection officials screening out reports that were made (Sedlak and Broadhurst, 1996). Estimating the incidence of child maltreatment is further complicated by the fact that a considerable amount occurs that is not known even to professionals.

In summary, thousands of children enter the juvenile victim justice system each year as a result of reports to police (mostly by victims and their families) and child protective services (mostly by professionals). However, the victimization of thousands of other children goes unreported.

\section{The Child Protection System}

How the juvenile victim justice system operates depends on whether the initial report is made to police or child protection authorities. This Bulletin describes the processes separately, starting with the child protection system. The path for the child protection system is shown at the top of the figure on page 3 , and the chronological steps, from left to right, are described below.

\section{Screening}

Because state laws require professionals to report "suspicions" of child abuse, the child protection system may receive reports on children who have not actually been victimized. Statistics including such reports can be misleading (e.g., "2.6 million abused children reported each year") (U.S. Department of Health and Human Services, 2001a). Child protection agencies screen out many of these reports, which are based on unfounded suspicions, con- tain too little or unreliable information, or do not fall within the agency's jurisdiction. Nationwide, about 67 percent of reports that the child protection system receives are accepted for investigation or assessment (U.S. Department of Health and Human Services, 2004). State agencies vary considerably in terms of what they are willing and able to investigate; some accept only very serious and specific allegations, whereas others conduct at least a minimal inquiry into a much broader range of reports (Wells, 1998). One study found that cases involving sexual abuse, allegations of drug use, families on welfare, and direct evidence of maltreatment were more likely to be investigated than cases involving custody disputes (Karski, 1999).

\section{Child Maltreatment Investigation}

At the start of any investigation into child maltreatment, the first objectives are to assess the situation and ensure the child's safety. Because children may be in danger, investigations conducted within the child protection system need to be timely. State laws require a response within a fixed period of time. Among states that report investigation response times, the average response takes about 3 days and varies from 5 hours to more than 2 weeks (U.S. Department of Health and Human Services, 2004). During the investigation stage, officials may authorize medical, mental health, or other experts to conduct an examination and an evaluation.

Investigations are not always part of the child protection process. As of 2001, 20 states had implemented an innovative, two-track system (Walter R. McDonald \& Associates, Inc., 2001). In this system, only serious allegations are investigated formally. When cases involve less serious allegations and lower levels of risk, child protection workers just assess the family for the possibility that it needs services. In states with such a two-track system, a majority of the reports (e.g., 71 percent in Missouri and 73 percent in Virginia) are handled on the "assessment only" track (Schene, 2001).

When necessary, investigators have the authority to take the child into custody on an emergency basis. In Connecticut, for example, child protection workers may remove children immediately for up to 4 days, typically with the help of the police, if the children have a serious physical illness or injury or are in immediate danger from their surroundings or from being unsupervised (State of Connecticut, Department of Children and Families, 2004).

Referral to police and prosecutors. Cases reported to the child protection system are referred to police and prosecutors primarily at the investigation stage. Some state laws require that certain types of maltreatment allegations be automatically referred to police or prosecutors. Other states allow more discretion when it comes to referring cases. The child protection system involves police when investigative help is required or as soon as evidence confirms that a criminal law has been violated. Referrals to the police are most consistent and immediate in cases involving allegations of sexual abuse, the death of a child, physical abuse (particularly serious injury), or brutality.

In some communities, police and child protection workers investigate independently (Cross, Finkelhor, and Ormrod, 2005). In others, police and child protection workers conduct coordinated investigations as part of a multiagency team. Some jurisdictions have experimented with turning investigation activities over to the police entirely (Cohen et al., 2002). Nationally, police are involved in more sexual abuse investigations (45 percent) than investigations involving physical abuse (28 percent) or neglect (20 percent) (Cross, Finkelhor, and Ormrod, 2005). Because of the differences in state laws and levels of interagency cooperation, investigative practices vary greatly among jurisdictions.

Medical examination. Medical examinations provide crucial evidence needed to substantiate a crime or child maltreatment. The examiners also assess children's overall medical needs and help young victims recover from a traumatic event by easing their worries and providing them with an opportunity to talk with a trusted authority. Many jurisdictions have specialized diagnostic units to perform these exams. Although the percentage varies, children receive medical exams in 10 to 25 percent of all reported sexual abuse cases (Berliner and Conte, 1995; Faller and Henry, 2000; Hibbard, 1998; Whitcomb et al., 1994).

Medical exams can disclose previous similar or related injuries, can determine whether injuries are consistent with the history given by caretakers or reporters, and can often distinguish injuries resulting from accidents or diseases from injuries 
that have been inflicted (Jenny, 2002). Examining injuries, genital physiology, semen, and hair can help confirm sexual abuse and identify perpetrators. Often, however, a medical examination can neither confirm nor disconfirm abuse. Definitive physical findings are established in only about one-quarter of examinations prompted by allegations of sexual abuse (Britton, 1998; Kerns, 1998).

\section{Substantiation of Child Maltreatment}

Investigations into child maltreatment result in a determination by the investigator as to whether maltreatment occurred, and this determination generally requires a preponderance of evidence as its standard of proof. The most common term for this is "substantiation"; however, other terms, such as "confirmation" or "support," are also used. Some states use the term "indicated," which means that evidence is consistent with child maltreatment but is not strong enough to substantiate (Depanfilis and Salus, 2003).

Nationwide, about 30 percent of all reports are substantiated-this percentage includes both substantiated and indicated reports (U.S. Department of Health and Human Services, 2004). This rate varies somewhat by type of maltreatment and varies dramatically by state. For example, in Massachusetts, allegations were confirmed in 55 percent of investigations in 2002, whereas in New Hampshire, only 9 percent were substantiated (U.S. Department of Health and Human Services, 2004). Historically, as the number of reports has risen, substantiation rates have declined. This phenomenon could reflect increasingly rigorous substantiation standards, a rise in the reporting of less serious situations, or proportionately fewer investigative resources within the child protection system.

Reports of child maltreatment may not be substantiated for a variety of reasons, including failure of the family or other informants to cooperate with the investigation, lack of sufficient evidence, allegations made outside the jurisdiction or authority of the agency, or an agency's inability to adequately investigate because of time or manpower constraints. The number of willfully false or malicious allegations is generally quite small (Everson and Boat, 1989; Jones and McGraw,
1987; Oates et al., 2000). The few states that count intentionally false allegations report that they occur in less than 1 percent of all cases (U.S. Department of Health and Human Services, 2004). In some cases, the substantiation process includes a form of plea bargaining, whereby reports are unsubstantiated or made for a less serious form of maltreatment (e.g., neglect rather than sexual abuse) in exchange for a commitment to accept services or other interventions (Eckenrode et al., 1988).

\section{Provision of Services}

An important goal of the child protection system is to prevent future maltreatment of the children it serves. To meet this goal, the child protection system offers preventive and remedial services such as counseling, parent education, and family support. According to state data, services are provided, on average, 7 to 8 weeks after an investigation begins (U.S. Department of Health and Human Services, 2004). About 59 percent of maltreated children receive services from the child protection system, but that percentage varies considerably among states, from 15 to 100 percent. Widespread concern exists that the child protection system does not adequately provide services. However, the fact that a large group of maltreated children do not appear to receive services from the child protection system does not necessarily indicate a failure in the provision of care (U.S. Department of Health and Human Services, 2004). For example, informal and familial solutions to child maltreatment situations (e.g., a parent moving in with grandparents) may be deemed adequate. Children and families may also receive services from other sources, such as family services or mental health agencies. In fact, referral to services may occur at almost every juncture in the juvenile victim justice system, including the criminal justice system (see the figure on p. 3; arrows omitted for the sake of simplicity).

\section{Court Hearing}

When child maltreatment is substantiated the case proceeds to a formal court hearing only when just cause exists to remove the child on more than an emergency basis or to take custody of the child. In 2002, court actions were initiated for 18 percent of the substantiated reports of child maltreatment (U.S. Department of Health and Human Services, 2004).

Child victims involved in such court proceedings require an advocate who will represent their needs and point of view and who is independent from the state agency bringing the action. Examples include court-appointed special advocates or guardians ad litem. According to reports from a limited number of states, about 18 percent of child victims received such representation (U.S. Department of Health and Human Services, 2004).

\section{Out-of-Home Placement}

Removing a child from his or her home is the child protection system's most serious intervention. In 2002, approximately 134,000 child victims-about 19 percent of those with a substantiated finding of child maltreatment-were removed from their homes (U.S. Department of Health and Human Services, 2004). Rates for individual states varied considerably. Most of the 42 states providing data reported rates between 9 percent and 34 percent; 2 states reported rates below that range, and 8 reported rates above it. Out of cases investigated for suspected child maltreatment, the rate of child removal is roughly 6 percent. An additional 67,000 child nonvictims (typically, siblings of the victims) were also removed. Some children were allowed to remain in their home, but only with supervision.

When removed from the home, children are placed in a variety of settings. According to the Adoption and Foster Care Analysis and Reporting system, three-fourths of children in foster care live with foster families: one-fourth with their relatives, and one-half with nonrelatives (Children's Bureau, 2001; U.S. Department of Health and Human Services, 2001b). About 10 percent of removed children are placed in institutions, and 8 percent are placed in group homes (these percentages include children placed in foster care for reasons other than child maltreatment). Some children are removed from their homes on an emergency basis during the investigation; however, most home removals are for a longer period of time and involve court action. The median length of stay for children in foster care, including victims of child maltreatment, is 16.5 months (Child Welfare Outcomes, 2001; U.S. Department of Health and Human Services, 2001b). Children removed to 
live with their relatives tend to stay for longer periods of time because the placement is generally viewed as a permanent one (Child Welfare Outcomes, 2001).

\section{Reunification}

Most children placed in foster care return to their families. In 1999, 66 percent of children exiting foster care returned to their families-ranging from 31 percent in Illinois to 85 percent in Idaho. A majority of the reunifications occurred within 12 months (Child Welfare Outcomes, 2001; U.S. Department of Health and Human Services, 2001b). Some children, however, need to re-enter foster care after reunification because of recurring maltreatment or a renewed risk of maltreatment.

\section{Termination of Parental Rights}

In the most serious cases of child maltreatment, the state moves to terminate parental rights and place a child for adoption. In 2000, parents of 64,000 children, or about 11 percent of those in foster care, had their parental rights terminated (Children's Bureau, 2001; U.S. Department of Health and Human Services, 2001b). Not all terminations resulted from child maltreatment. Based on a rough annual estimate of 800,000 substantiated victims of child abuse and neglect, the rate of termination of parental rights for substantiated child maltreatment cases is about 8 percent.

\section{Summary}

The child protection system's primary goal is to ensure children's safety, but it also seeks to facilitate the delivery of needed services. On average, about 67 percent of the reports submitted to child protection services are investigated. Nationally, about 30 percent of investigations lead to substantiation, though this rate varies greatly by state. The child protection system can initiate various interventions during, or as a result of, an investigation, including medical examinations, referral to the criminal justice system, and the delivery of services from child protection and other agencies. Removing children from their homes on an emergency basis or as a result of a court hearing is fairly rare, and most removed children are later reunified with their families.

\section{The Criminal Justice System}

In addition to the referrals it gets from the child protection system, the criminal justice system receives many reports on child victimization from victims, families, and schools and other institutions. Because the criminal justice system deals with all types of crime, including child maltreatment, criminal justice system cases involving child victims are very different from cases reported to the child protection system. Most cases involving child victims reported to the criminal justice system (about 70 percent) involve a nonfamily perpetrator, and more than half are youth-on-youth offenses (Finkelhor and Ormrod, 2000a). Very few criminal justice cases involve simple neglect or emotional abuse. As mentioned earlier, the majority of the victims are teenagers (Finkelhor and Ormrod, 2000a). The criminal justice system also receives approximately 400,000 reports per year involving juveniles who are victims of property crimes (Finkelhor and Ormrod, 2000b).

The path that cases entering the criminal justice system take is illustrated in the figure on page 3. Again, the steps in the process are depicted in chronological order, from left to right. Because most victim-specific research on case processing within the criminal justice system is limited to cases of sexual assault, sexual abuse, and other serious offenses, little is known about juveniles in the justice system who are victims of simple assault, crimes by other youth, and property crimes.

\section{Criminal Justice Investigation}

Although police usually investigate reports of juvenile victimization, little research exists on the numbers, percentages, or circumstances related to such investigations. For this Bulletin, data from the National Crime Victimization Survey, a national study that interviewed crime victims, were analyzed. After a case was reported, police made contact with juvenile victims (ages 12 to 17 ) in 92 percent of violent crimes and 79 percent of property crimes. For these same cases, police took a report (that is, collected information about the crime) in 63 percent of violent crimes and 72 percent of property crimes.

If reports to and investigations made by police lead to a suspicion of child maltreatment, police are required to report this suspicion to child protection services. Unfortunately, no data exist regarding how often referrals are made from the criminal justice system to the child protection system.

\section{Arrest}

An arrest is made when police, after finding probable cause that a person has committed a crime, locate and apprehend that person. However, police make an arrest in only a minority of juvenile victim crimes that come to their attention. An analysis of data from the National Crime Victimization Survey shows that offenders are arrested in 28 percent of violent crimes and only 4 percent of property crimes involving juvenile victims. (According to data from the Federal Bureau of Investigation's National Incident-Based Reporting System, the arrest rate for violent crimes involving juvenile victims is 32 percent.) Physical assaults on juvenile victims have somewhat lower arrest rates than assaults on adult victims, but sexual assault crimes against juveniles have higher arrest rates than sexual assaults on adults (Rezac and Finkelhor, 2002). The low arrest rates reflect the limited resources that police have, the absence of information about offenders in many cases (particularly in property crimes), and the fact that many crimes with juvenile victims are judged to be relatively minor in nature.

Arrests are more common in juvenile victimizations involving a weapon and other serious offenses, such as sexual assaults and aggravated assaults (Rezac and Finkelhor, 2002). Arrests are less likely when the perpetrator is a stranger because locating the offender to make an arrest is more difficult. A relatively large number of offenders who victimize juveniles (more than 50 percent) are other juveniles, which is an important feature of juvenile victimization that affects arrests and other aspects of criminal justice activity (Finkelhor and Ormrod, 2000a). Offenses committed by juveniles are handled by the institutions and procedures of the juvenile justice system. Though somewhat less formal and less public than those of the criminal justice system, juvenile justice procedures include analogs to trials (adjudicatory hearings) and sentencing (disposition hearings), at which victims may testify, and unique features, such as victimoffender mediation. (To keep the figure 
on page 3 relatively simple, specific components of the juvenile offender justice system are excluded; however, a diagram of that system is available in Snyder and Sickmund, 1999.) Although a large amount of research literature exists on the workings of the juvenile justice system, the experiences of juvenile victims whose offenders are processed in this system have not been extensively examined.

\section{Victim Compensation}

Most states have systems that compensate victims of crime for the costs associated with medical care, counseling, home and auto repair, and replacing stolen items. To obtain compensation, victims must file applications, which victim compensation boards review. Although victims may file claims at any point in the criminal justice process, police referrals prompt many claims. An offender does not need to be convicted for compensation to be awarded to a victim (National Association of Crime Victim Compensation Boards, 2003a).

Nationwide, of those victims receiving compensation, 22 percent were child abuse victims (National Association of Crime Victim Compensation Boards, 2003b), and more than $\$ 37$ million were provided for services for these victims. Interestingly, more than half of this allocation was spent in California, which has an active record of using victim compensation to support psychotherapy for child victims. No data exist, however, on what percentage of eligible children apply. Nationally, more than 45,000 claims were approved for victims age 17 and younger, but more may be eligible. A perception exists that many victims are unaware of the availability of victim compensation funds.

\section{Decision To Prosecute}

Cases are referred to a prosecutor in conjunction with an investigation or after an arrest has been made. Although decisions about prosecution vary considerably from jurisdiction to jurisdiction, prosecutors almost always evaluate the strengths and weaknesses of the case and the likelihood of success before deciding to proceed, sometimes after talking with victims and other witnesses. Prosecutors also consider the potential negative effects of trials on child victims. In many jurisdictions, prosecutors bring a case before a judge, in a preliminary hearing, and a grand jury to determine if probable cause exists. (Children may testify in both situations.) If probable cause is not established, the case is dismissed.

Offenders may be arrested before or after the decision to prosecute. If police have made an arrest, cases are almost always forwarded to prosecutors (Davis and Wells, 1996). Once referred for prosecution, the proportion of child victim cases that proceed to prosecution varies widely. In 13 studies that Cross et al. (2002) reviewed, the proportion of child abuse cases in which charges were brought against the perpetrator ranged from 28 to 94 percent, with a median of 66 percent. Rates differ considerably across prosecutors' offices, not only because of the resources they have and the priority they give to child victim cases, but also because of differences in which cases are referred to prosecutors and which cases are not. Prosecution is less likely when child victims are younger than age 7 , when children are related to the perpetrator, and when they suffer less severe offenses (Mennerich et al., 2002). Most likely, these variables correspond to the availability of evidence and children's capacity to talk about the abuse and testify in court. The grand jury, the judge, or prosecutors themselves can later dismiss cases that the prosecutor has accepted. However, in the Cross et al. (2002) sample, an average of 79 percent of cases proceeded without dismissal.

\section{Pleading Guilty Versus Going to Trial}

If a case is accepted by a prosecutor and not dismissed, a disposition is reached either by a guilty plea or by a trial. When cases involving child victims are sent forward without dismissal, the likelihood that the offender will plead guilty is high. According to a review of 19 studies examining the prosecution of child abuse cases, an average of 82 percent of offenders against children pled guilty to at least some charge (Cross et al., 2002), which is about the same as the percentage of general violent offenders and very close to the 76 percent of general sexual assault offenders who plead guilty. This consistency reflects the fact that prosecutors go forward only with fairly strong cases in which they can exert considerable leverage negotiating charges and sentences. Still, in about 19 percent of the examined cases, prosecutors failed to obtain a plea and the cases went to trial.

\section{Sentencing}

Data from 14 studies of cases in which offenders were prosecuted for child abuse reveal that 54 percent (the median rate) of convicted offenders were incarcerated, although the rates varied from 24 to 96 percent (Cross et al., 2002). In the past, considerable media attention has focused on whether offenders against juveniles receive unusually lenient sentences. An analysis of sentences from a national sample of adult offenders incarcerated in state correctional facilities found that some of the sentencing disparities were explained by the fact that adult offenders against juveniles are less likely to be recidivists, less likely to use weapons, and less likely to be strangers to their victims-factors associated with shorter sentences (Finkelhor and Ormrod, 2001). Even after controlling for such variables, some sentencing disparities related to victim age did exist, but they involved adult offenders against adolescents (age 12 and older), who tended to receive shorter sentences. Evidence does not indicate a leniency toward offenders simply because their victims are young children (Finkelhor and Ormrod, 2001).

\section{Summary}

Police investigate most reported crimes involving juvenile victims, but arrests are made in only a minority of such cases. When an arrest is made, most cases are referred to prosecutors, but the proportion that prosecutors accept varies from about 50 to 75 percent. Generalizing from sexual assault crimes, cases tend to be dropped on the basis of concerns about evidence and children's ability to testify. Of the cases carried forward, however, 80 percent end with guilty pleas. Offenders against young juvenile victims do not receive systematically lighter sentences than offenders against adult victims, but sentences may be lighter for offenders against adolescents. Juvenile victims comprise a sizable proportion of those who receive victim compensation awards; however, many victims may not be aware of those funds.

\section{Impact of the Juvenile Victim Justice System on Victims}

As described above, cases with juvenile victims may involve a number of institutions that are part of the juvenile victim 
justice system, but not all of the institutions have an immediate or direct impact on juvenile victims. For example, an offender may be charged, plead guilty, be sentenced, and enter prison without a victim ever having to see anyone, appear anywhere, or even necessarily know about the events. This situation is not typical, but it is theoretically possible in cases with considerable physical evidence, eyewitnesses, and perpetrators who cooperate with authorities.

Identifying the components of the child protection system and the criminal justice system that have the most frequent and consequential effect on victims is an important part of conceptualizing the juvenile victim justice system. Three specific impacts are important to consider: (1) interviews and appearances that child victims must make before officials, (2) direct therapeutic or reparative services that child victims receive, and (3) family disruptions or other disruptions resulting from institutional decisions within the system. These impacts, which can be charted in terms of their sequencing and likelihood of occurrence, are an important adjunct to understanding how the juvenile victim justice system works. These impacts are represented throughout the figure (page 3); the type of victim involvement and its probability correspond to the ovals in the key.

The impact of the victim justice system is not confined to these three types of events. Some of the most consequential impacts may involve information that a victim receives indirectly. For example, a victim may be told or find out that the prosecutor refused to press charges against the offender or that a perpetrator's attorney called the victim a liar, events that may be extremely distressing. However, those impacts are more difficult to classify.

\section{Interviews, Medical Exams, and Testimony}

Of all the events that affect victims, the one that occurs most often is an investigative interview. If the victimization is reported to police, an officer will likely interview the juvenile. When a victimization is reported to child protection services, someone from that system will almost always talk to the child unless the child is very young. An interview with a police officer occurs in 92 percent of violent crimes with juvenile victims reported to the police (according to the National
Crime Victimization Survey). An investigation, which typically involves a child interview, occurs in 60 percent of child maltreatment reports recorded by the National Child Abuse and Neglect Data System (U.S. Department of Health and Human Services, 2004). Some cases require more than one investigative interview, which can occur as investigators try to gather additional evidence or when another agency becomes involved (e.g., a case referred from child protection services to the police or vice versa). Analyzing prosecutor case data from 1988-91, Smith and Elstein (1993) found that children were interviewed by law enforcement in 96 percent of cases and by child protection services in 46 percent. These interviews were conducted separately 64 percent of the time, so children often had to tell their stories more than once.

Reducing the number of duplicative investigative interviews and thus their possible negative impact on victims has been a driving force behind the development of multidisciplinary teams and Children's Advocacy Centers. It also has been an important motive behind the effort to videotape investigative interviews more routinely. The development nationwide of several hundred Children's Advocacy Centers and other multidisciplinary programs during the 1990s may have reduced the amount of duplicative interviewing, although confirmation of this trend is needed (Simone et al., 2005).

As part of an investigation, approximately 22 percent of victimized children will receive a medical exam (National Association of Crime Victim Compensation Boards, 2003b). Victims of sexual abuse and physical abuse involving injury are more likely to receive such exams. These exams can be stressful, but one study found it equivalent to providing testimony in juvenile court-twice as stressful as talking to a social worker, but not nearly as stressful as testimony in criminal court (Runyan, 1998).

Child victims may be interviewed at a number of subsequent junctures in the juvenile victim justice system. Prosecutors may decide to interview children again after the police investigation, while making the decision about whether to prosecute and trying to assess the strength of the testimony. As part of the process, a child may be asked to testify at a preliminary hearing or grand jury. Studies report that 12 percent to 31 percent of children in prosecuted cases testify at pretrial proceedings (Cashmore and Horsky, 1988; Cross, Whitcomb, and De Vos, 1995; Goodman et al., 1992; Smith and Elstein, 1993). If the case goes to trial, the child may testify again, often in conjunction with prior meetings with the prosecutor. However, because so many cases end with guilty pleas, relatively few children have to testify in trial court. Only between 5 and 15 percent of cases involve a child victim's testimony at a trial or a court hearing (Berliner and Conte, 1995; Cashmore and Horsky, 1988; Cross, Whitcomb, and De Vos, 1995; Goodman et al., 1992; Martone, Jaudes, and Cavins, 1996; Rogers, 1982). Voluntary opportunities for a victim to testify at a sentencing hearing may also occur (U.S. Department of Justice, 1999).

\section{Services}

A specific goal of investigations that child protection services conduct is to promote the well-being of victimized children through needed services. As indicated earlier, about 59 percent of maltreated children are referred for services. Police or prosecutors also may refer children as part of criminal justice system processing; however, little systematic documentation about this referral pathway exists, and such referrals are probably not as frequent as those from child protection services. Some services are clearly beneficial. For example, cognitive-behavioral therapy that teaches sexually abused children and their families how to cope with the effects of abuse has been proven to be more beneficial than standard care (Cohen, Berliner, and Mannarino, 2000; Cohen and Mannarino, 1997; Deblinger, Stauffer, and Steer, 2001).

\section{Family Disruption}

The juvenile victim justice system can have a major impact on child victims when it causes family disruption-that is, a major change in living circumstances or the household configuration. One form of disruption may occur early in the process if a child protection worker uses emergency power to remove an endangered child from his or her home. A disruption may also occur if the police arrest and hold a parent suspected of a crime against a child. At later stages in the child protection process, the court may remove a child from the home, either temporarily for foster care placement or later as part of the termination of parental rights. 
Reunifications are frequently part of the system process, and they can create other disruptions. The sentencing of an intrafamilial abuser to prison may also disrupt the family. Although all these events may have major impacts on children, they occur in only a minority of child victimization cases.

\section{Implications}

This Bulletin describes in general terms the operation of the juvenile victim justice system and what is known about how cases move through it. Recognizing that such a system exists and often contributes to, but sometimes detracts from, the justice, safety, and physical and psychological well-being of juvenile victims has important implications, which are described below.

Policy and practice. More people need to understand the operation of the juvenile victim justice system in its entirety. Agency administrators and line workers need to know more about the other agencies in the system, and policymakers and researchers need to be more familiar with the system as a whole. Such knowledge is important for planning policy and managing individual cases so that decisions made in one part of the system can fully take into account actions that may occur in other parts.

Policymakers need to focus on identifying and prioritizing the most important stages and transitions of the juvenile victim justice system. For a long time, concern about child victims in criminal court concentrated policy attention on ways to mitigate the stress on children having to testify in criminal cases. However, a systems-level analysis demonstrated that only a small percentage of juvenile victims face the prospect of testifying in criminal court. In contrast, issues related to the stress and efficacy of child protection interviews or medical examinations may affect a greater percentage of children. Policy that helps answer questions about why arrests are not made in so many child victim cases or what techniques lead to guilty pleas may result in better outcomes for child victims.

Victim assistance. Juvenile victims need the assistance of professionals who can orient, guide, and support them and their families during their involvement with the juvenile victim justice system. Professionals working for Children's Advocacy Centers or serving as court-appointed special advocates and guardians ad litem play such roles, but often only for a part of the system process. Such support should be much more comprehensive and continuous.

System integration. More consideration needs to be given to integrating and rationalizing the system as a whole. In recent years, considerable effort has been devoted to trying to coordinate certain aspects of the juvenile victim justice system-for example, by conducting joint investigations or developing multidisciplinary teams for sharing information and decisionmaking. However, more dramatic forms of integration might be possible. For example, the responsibilities associated with applying criminal sanctions, making decisions related to child custody and services provision, and awarding victim compensation funds might be centralized into a single judicial institution. Such an integration would seek to expedite processes, coordinate decisions, and minimize the negative impacts on victims. Where separation between components of the system is necessary (e.g., between criminal justice and support for families), better methods are required for assessing where cases belong and for moving cases between parts of the system as needs change.

Information sharing. The juvenile victim justice system requires more efficient information exchange among its components. A child can be involved with up to six or seven agencies and a dozen or more professionals over a course of interventions that can last several years. Information from one part of the system can affect decisions made in other parts. The criminal investigation of an alleged perpetrator living in a victim's home, for instance, may influence the child protection system's decision to place the child outside the home. The need for confidentiality sets limits, yet information sharing among agencies often falls short because it is a secondary priority for busy professionals. Whitcomb and Hardin (1996), for example, found that communication between criminal and civil court staff on simultaneous proceedings regarding the same child was often minimal or nonexistent-a situation that increases the risk that the two courts may make contradictory decisions. When communication is present, it tends to occur in the early phases and is often not maintained throughout the child's contact with the system. Case review and case-tracking systems are steps in the right direction, but no central repository of information exists. New methods and technologies for ensuring the adequate flow of information need to be developed.

Service delivery. Greater attention needs to be given to the fact that the juvenile victim justice system can be the entry point for needed services for thousands of victimized children. Agencies that provide services to children and families tend to think about their referral sources as simply other individuals and agencies. Often, the identification of a need for service is viewed as occurring on a caseby-case basis. However, when referral patterns are considered as part of a system involving large numbers of children with service needs, new realities come into focus. For example, the demand made on some children to talk about their victimization at many points in the system over an extended period of time suggests the need for human services professionals to provide children with systemwide support throughout the process. The fact that many child victims with service needs related to trauma or inadequate care come through the system at predictable junctures suggests new places, times, and programming possibilities for addressing children's needs.

Data collection. Systematic and comprehensive information needs to be collected about the operation of the juvenile victim justice system and the interrelationships among its components. Tremendous gaps in information exist, and virtually no data collection effort covers the entire system. Several steps are needed: Pilot studies should be undertaken to track juvenile victims through all the steps and stages in the system. Data elements need to be added to current information systems that track interrelationships. For example, police data that the National IncidentBased Reporting System gathers could record whether a crime was referred to police from child protection services. Data from the child protection system could record whether an arrest was made. In addition, although serious privacy concerns may be raised, having the different systems record victims using a common identifier might make tracking victims through various databases possible, thereby uncovering the pathways through the interrelated systems.

System assessment. Efforts need to be made to characterize and summarize in a comprehensive way how the juvenile victim justice system operates in different 


\section{Data Sources}

Many of the statistics on case flow in this Bulletin come from three sources: the National Child Abuse and Neglect Data System (NCANDS), the National Incident-Based Reporting System (NIBRS), and the National Crime Victimization Survey (NCVS).

NCANDS annually gathers and publishes data that the child protection agencies in individual states collect. Although NCANDS provides guidelines for states to use in their data collection, not all states use identical definitions or categories, which results in some problems when data are aggregated. More information about NCANDS is available at www.ndacan.cornell.edu.

NIBRS is an emerging effort by the U.S. Department of Justice to collect more detailed information about crime from local law enforcement. It allows, for the first time, crimes against juveniles to be disaggregated from crimes against adults. However, the data came from jurisdictions in only 17 states in 1999, providing coverage for 11 percent of the nation's population and 9 percent of its crime. Only three states (Idaho, lowa, and South Carolina) had full participation by all local jurisdictions, and only one city with a population greater than 500,000 (Austin, TX) reported. As a result, the crime experiences of large urban areas are particularly underrepresented in this data system. More information about NIBRS can be found at www.ojp. usdoj.gov/bjs/nibrs.htm.

NCVS is a national survey of the U.S. population age 12 and older that the Bureau of the Census conducts on behalf of the U.S. Department of Justice. The active sample consists of approximately 55,000 households and approximately 100,000 individual respondents. It gathers a wide range of information from citizens regarding crime victimizations, including experiences with law enforcement. However, the survey is limited to specific types of victimizations (i.e., the violent crimes of physical assault, rape, sexual assault, and robbery, and the property crimes of larceny and motor vehicle theft). It provides no information about victims younger than age 12. More information about NCVS is available at www.icpsr.umich.edu/NACJD/NCVS. communities. Key dimensions need to be delineated so systems can be compared and contrasted. For example, a comparative study might help establish criteria for integrating systems or making them victim-oriented.

Considering implications such as these can help create a justice system more responsive to the needs of the thousands of juvenile victims who encounter it every year.

\section{References}

Berliner, L., and Conte, J. 1995. The effects of disclosure and intervention on sexually abused children. Child Abuse \& Neglect 19(3):371-384.

Britton, H. 1998. Emotional impact of the medical examination for child sexual abuse. Child Abuse \& Neglect 22(6): 573-579.

Cashmore, J., and Horsky, M. 1988. The prosecution of child sexual assault. Australian and New Zealand Journal of Criminology 21:241-252.

Child Welfare Outcomes. 2001. Technical Report, 1999. Arlington, VA: James Bell Associates.

Children's Bureau. 2001. The Adoption and Foster Care Analysis Reporting System Preliminary Report. Washington, DC: U.S. Department of Health and Human Services, Administration on Children, Youth and Families.

Cohen, B., Kinnevy, S., Huang, V., Gelles, R., Bae, H.O., and Fusco, R. 2002. Evaluation of the Transfer of Response for Child Protective Investigations to the Broward County Sheriff's Office. Philadelphia, PA: University of Pennsylvania, Center for the Study of Youth Policy.

Cohen, J.A., Berliner, L., and Mannarino, A.P. 2000. Treating traumatized children: A research review and synthesis. Trauma, Violence, \& Abuse 1(1):29-46.

Cohen, J.A., and Mannarino, A.P. 1997. A treatment study for sexually abused preschool children: Outcome during a oneyear follow-up. Journal of the American Academy of Child and Adolescent Psychiatry 36(9):1228-1235.

Cross, T.P., Finkelhor, D., and Ormrod, R.K. 2005. Police involvement in child protective services investigations. Child Maltreatment 10(3):224-244.
Cross, T.P., Walsh, W., Jones, L.M., and Simone, M. 2002. Prosecution of child abuse: A meta-analysis of rates of criminal justice decisions. Trauma, Violence, \& Abuse 4:323-340.

Cross, T.P., Whitcomb, D., and De Vos, E.D. 1995. Criminal justice outcomes of prosecution of child sexual abuse: A case flow analysis. Child Abuse \& Neglect 19(12): 1431-1442.

Davis, N.S., and Wells, S.J. 1996. Justice System Processing of Child Abuse and Neglect Cases. Final Report. Washington, DC: American Bar Association Center on Children and the Law.

Deblinger, E., Stauffer, L.B., and Steer, R.A. 2001. Comparative efficacies of supportive and cognitive behavioral group therapies for young children who have been sexually abused and their non-offending mothers. Child Maltreatment 6:332-343.

Depanfilis, D., and Salus, M.K. 2003. Child Protective Services: A Guide for Caseworkers: Child Abuse and Neglect User Manual Series. Washington, DC: U.S. Department of Health and Human Services, Children's Bureau, Office of Child Abuse and Neglect.

Eckenrode, J., Powers, J., Doris, J., Munsch, J., and Bolger, N. 1988. Substantiation of child abuse and neglect reports. Journal of Consulting and Clinical Psychology 56(1):9-16.

Everson, M., and Boat, B. 1989. False allegations of sexual abuse by children and adolescents. Journal of the American Academy of Child and Adolescent Psychiatry 28(2):230-235.

Faller, K.C., and Henry, J. 2000. Child sexual abuse: A case study in community collaboration. Child Abuse \& Neglect 24(9):1215-1225.

Finkelhor, D., and Ormrod, R.K. 1999. Reporting Crimes Against Juveniles. Bulletin. Washington, DC: U.S. Department of Justice, Office of Justice Programs, Office of Juvenile Justice and Delinquency Prevention.

Finkelhor, D., and Ormrod, R.K. 2000a. Characteristics of Crimes Against Juveniles. Bulletin. Washington, DC: U.S. Department of Justice, Office of Justice Programs, Office of Juvenile Justice and Delinquency Prevention. 
Finkelhor, D., and Ormrod, R.K. 2000b. Juvenile Victims of Property Crimes. Bulletin. Washington, DC: U.S. Department of Justice, Office of Justice Programs, Office of Juvenile Justice and Delinquency Prevention.

Finkelhor, D., and Ormrod, R.K. 2001. Offenders Incarcerated for Crimes Against Juveniles. Bulletin. Washington, DC: U.S. Department of Justice, Office of Justice Programs, Office of Juvenile Justice and Delinquency Prevention.

Finkelhor, D., and Wolak, J. 2003. Reporting assaults against juveniles to the police: Barriers and catalysts. Journal of Interpersonal Violence 18(2):103-128.

Goodman, G.S., Taub, E.P., Jones, D.P., England, P., Port, L.K., Rudy, L., and Prado, L. 1992. Testifying in criminal court: Emotional effects on child sexual assault victims. Monographs of the Society for Research in Child Development 57(5): 142-229.

Hibbard, R.A. 1998. Triage and referrals for child sexual abuse medical examinations from the sociolegal system. Child Abuse \& Neglect 22(6):503-513.

Jenny, C. 2002. Medical issues in child sexual abuse. In The APSAC Handbook of Child Maltreatment, $2 \mathrm{~d}$ ed., edited by J.E.B. Myers, L. Berliner, J. Briere, C.T. Hendrix, C. Jenny, and T.A. Reid. Thousand Oaks, CA: Sage Publications, pp. 235-247.

Jones, D.P., and McGraw, J.M. 1987. Reliable and fictitious accounts of sexual abuse to children. Journal of Interpersonal Violence 2:27-45.

Karski, R.L. 1999. Key decisions in child protective services: Report investigation and court referral. Children and Youth Services Review 21(8):643-656.

Kerns, D.L. 1998. Triage and referrals for child sexual abuse medical examinations: Which children are likely to have positive medical findings. Child Abuse \& Neglect 22(6):515-518.

Martone, M., Jaudes, P.K., and Cavins, M. 1996. Criminal prosecution of child sexual abuse cases. Child Abuse \& Neglect

20(5):457-464.

Mennerich, A.L., Martell, D., Cross, T.P., and White, A. 2002. Case and system predictors of prosecution of child abuse. Unpublished manuscript. Washington, DC: American University.
National Association of Crime Victim Compensation Boards. 2003a. Compensation for Crime Victims. Brochure. Retrieved February 23, 2003, from the Web: www. nacvcb.org/documents/BrochureCVC.pdf.

National Association of Crime Victim Compensation Boards. 2003b. Home page. Retrieved February 23, 2003, from the Web: www.nacvcb.org/index.html.

Norris, F.H., and Kaniasty, K. 1994. Psychological distress following criminal victimization in the general population: Crosssectional, longitudinal, and prospective analyses. Journal of Consulting and Clinical Psychology 62(1):111-123.

Oates, R.K., Jones, D.P., Denson, D., Sirotnak, A., Gary, N., and Krugman, R.D. 2000. Erroneous concerns about child sexual abuse. Child Abuse \& Neglect 24(1): 1049-157.

Ormrod, R.K. 2002. Reports to police by source: NCVS-2000. Unpublished raw data. Durham, NH: University of New Hampshire.

Rezac, S., and Finkelhor, D. 2002. Arrest patterns for offenders against juveniles. Unpublished manuscript. Durham, NH: University of New Hampshire.

Rogers, C.M. 1982. Child sexual abuse and the courts: Preliminary findings. Social Work and Human Sexuality 1(1):145-153.

Runyan, D. 1998. Discussion: Emotional impact of the child sexual abuse medical examination. Child Abuse \& Neglect 22(6):585.

Schene, P. 2001. Meeting each family's needs: Differential response in reports of child abuse and neglect. In Best Practice/Next Practice: Family-Centered Child Welfare, vol. 2, edited by National Child Welfare Resource Center for FamilyCentered Practice. Washington, DC: National Child Welfare Resource Center for Family-Centered Practice, pp. 1-14.

Sedlak, A.J., and Broadhurst, D.D. 1996. Third National Incidence Study of Child Abuse and Neglect. Washington, DC: U.S. Department of Health and Human Services.

Simone, M., Cross, T.P., Jones, L.M., and Walsh, W. 2005. Children's advocacy centers: Understanding the impact of a phenomenon. In Child Victimization, edited by K. Kendall-Tackett and S. Giacomoni. New York, NY: Civic Research Institute, pp. 22.21-22.24.
Smith, B.E., and Elstein, S.G. 1993. The Prosecution of Child Sexual and Physical Abuse Cases: Final Report. Washington, DC: The National Center on Child Abuse and Neglect.

Snyder, H.N., and Sickmund, M. 1999. Juvenile Offenders and Victims: 1999 National Report. Washington, DC: U.S. Department of Justice, Office of Justice Programs, Office of Juvenile Justice and Delinquency Prevention.

State of Connecticut, Department of Children and Families. 2004. Department of children and families policy manual. Retrieved June 5, 2004, from the Web: www.state.ct.us/dcf/Policy/Invest34/ 34-10-4.htm.

U.S. Department of Health and Human Services, Administration on Children, Youth and Families. 2001a. Child Maltreatment 1999. Washington, DC: U.S. Government Printing Office.

U.S. Department of Health and Human Services, Administration on Children, Youth and Families. 2001b. Safety, Permanency, Well-Being. Child Welfare Outcomes 1999: Annual Report. Washington, DC: U.S. Government Printing Office.

U.S. Department of Health and Human Services, Administration on Children, Youth and Families. 2004. Child Maltreatment 2002: Reports From the States to the National Child Abuse and Neglect Data System. Washington, DC: U.S. Government Printing Office.

U.S. Department of Justice. 1999. Attorney General Guidelines for Victim and Witness Assistance, 2000. Rockville, MD: Office of Victims of Crime Resource Center.

Walter R. McDonald \& Associates, Inc. 2001. National Study of Child Protective Services Systems and Reform Efforts. Washington, DC: U.S. Department of Health and Human Services, Administration on Children, Youth and Families.

Wells, S.J. 1998. Responding to reports of child abuse and neglect. Paper presented at the American Association for Protecting Children 112th Annual Conference, Washington, DC.

Whitcomb, D., Goodman, G.S., Runyan, D.K., and Hoak, S. 1994. The Emotional Effects of Testifying on Sexually Abused Children. Research in Brief. Washington, DC: U.S. Department of Justice, Office of Justice Programs, National Institute of Justice. 
Office of Justice Programs

Office of Juvenile Justice and Delinquency Prevention

Washington, DC 20531

Official Business

Penalty for Private Use $\$ 300$

Whitcomb, D., and Hardin, M. 1996. Coordinating Criminal and Juvenile Court Proceedings in Child Maltreatment Cases. Research Preview. Washington, DC: U.S. Department of Justice, Office of Justice Programs, National Institute of Justice.

This Bulletin was prepared under grant numbers 1999-JP-FX-1101 and 01-JN-FX-0009 from the Office of Juvenile Justice and Delinquency Prevention, U.S. Department of Justice.

Points of view or opinions expressed in this document are those of the authors and do not necessarily represent the official position or policies of OJJDP or the U.S. Department of Justice.

The Office of Juvenile Justice and Delinquency Prevention is a component of the Office of Justice Programs, which also includes the Bureau of Justice Assistance, the Bureau of Justice Statistics, the National Institute of Justice, and the Office for Victims of Crime.

\section{Acknowledgments}

David Finkelhor, Ph.D., is Professor of Sociology and Director, Crimes against Children Research Center, University of New Hampshire. Theodore P. Cross, Ph.D., is Senior Scientist, RTI International. Elise N. Cantor, Ph.D., is an assistant professor at Utica College.

The authors would like to thank Kelly Foster, Julie Pardus-Oakes, and members of the University of New Hampshire Family Violence Research Seminar for their help with this Bulletin. 